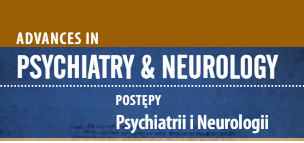

Correspondence to/Adres do korespondencji:

Rachela Antosz-Rekucka

Jagiellonian University

Doctoral School in the Social Sciences

4 prof. St. Łojasiewicza St.

30-348 Krakow, Poland

e-mail: r.antoszrekucka@gmail.com

Submitted/Otrzymano: 13.07.2021

Accepted/Przyjęto do druku: 08.11.2021

\section{The sense of coherence in healthy individuals with psychotic-like experiences}

\section{Poczucie koherencji u zdrowych osób z doświadczeniami podobnymi do psychotycznych}

\author{
Rachela Antosz-Rekucka (D)
}

Jagiellonian University, Doctoral School in the Social Sciences, Krakow, Poland

\begin{abstract}
Purpose: Psychotic-like experiences (PLEs) are subclinical symptoms of psychosis that can be observed in general population. They share many characteristics with psychosis and may, but do not have to, precede the development of psychotic disorders. Sense of coherence (SOC) is a global orientation which helps a person successfully cope with the demands of life, and stay healthy. A SOC level expresses how much a person believes that the world is predictable and coherent, and has been shown to be related to psychological functioning. It consists of the three components: comprehensibility, manageability, and meaningfulness. The aim of the study was to test the relationship between SOC and PLEs, which has not been tested before.

Methods: The research comprised the pilot and the main study. The study samples consisted of 82 and 215 adults respectively. Psychiatric disorders or the use of psychoactive substances 3 months prior to the study were the exclusion criteria. SOC and PLEs were measured with self-report questionnaires. Correlation and regression analyses were performed to examine the relationship between the study variables.

Results: SOC was found to be strongly and negatively correlated with PLEs. Also, SOC was determined to be a non-redundant, negative predictor of psychotic-like experiences. When SOC components (comprehensibility, manageability, and meaningfulness) were tested separately as predictors, meaningfulness was found to be a negative predictor of negative PLEs and a positive predictor of positive PLEs.

Conclusion: The results suggest that SOC is an important factor negatively related to PLEs. Further studies are required to verify whether high-level SOC may be a factor preventing the development of PLEs.

Key words: sense of coherence, general population, salutogenesis, psychotic-like experiences, psychosis-continuum hypothesis.
\end{abstract}

\title{
Streszczenie
}

Cel: Doświadczenia podobne do psychotycznych (psychotic-like experiences - PLEs) to przeżycia przypominające objawy psychozy, występujące u osób zdrowych. Obserwuje się wiele podobieństw między PLEs a psychozą, mogą też one - choć nie muszą - prowadzić do rozwoju zaburzeń psychicznych. Poczucie koherencji (sense of coherence - SOC) to uogólnione nastawienie, które pomaga skutecznie radzić sobie z wyzwaniami życia i zachowywać zdrowie. Jego poziom oddaje, do jakiego stopnia osoba postrzega świat jako przewidywalny i spójny. Wykazano też, że wiąże się ono z funkcjonowaniem psychicznym. Poczucie koherencji składa się $\mathrm{z}$ trzech komponentów: poczucia zrozumiałości, sterowalności i sensowności. Celem badania było sprawdzenie relacji pomiędzy PLEs a SOC, ponieważ nie była ona badana.

Metody: Przeprowadzono badanie pilotażowe i główne. Grupy badawcze składały się kolejno z 82 i 215 zdrowych osób dorosłych. Do analizy PLEs i SOC wykorzystano samoopisowe kwestionariusze. Przeprowadzono analizy korelacji i regresji.

Wyniki: Poczucie koherencji było silnie negatywnie związane z PLEs. Było też ich istotnym negatywnym predyktorem. Kiedy komponenty SOC (poczucie zrozumiałości, sterowalności i sensowności) zostały uwzględnione osobno w analizach regresji, poczucie sensowności okazało się ujemnym predyktorem negatywnych PLEs i predyktorem dodatnim pozytywnych PLEs.

Wnioski: Wyniki sugerują, że SOC jest istotnym czynnikiem negatywnie związanym z PLEs. Wymagane są dalsze badania, aby sprawdzić, czy może ono być czynnikiem chroniącym przed rozwojem PLEs.

Słowa kluczowe: poczucie koherencji, populacja ogólna, salutogeneza, doświadczenia podobne do psychotycznych, hipoteza kontinuum psychotycznego. 


\section{INTRODUCTION}

Psychotic-like experiences (PLEs) are subclinical positive and negative symptoms of psychosis that can be observed in healthy population [1], such as delusion-like beliefs, hallucination-like experiences, emotional withdrawal, apathy, and anhedonia. PLEs differ from fullyblown psychosis in the level of intrusiveness and frequency [1]. Although most PLEs are transient and do not necessarily turn into mental disorders, persistent PLEs may constitute an important risk factor for development of psychosis $[2,3]$. Moreover, PLEs show many similarities to psychosis, and occur more frequently in groups with higher risk of developing psychosis, i.e., single, unemployed people with lower-level education, men, drug-users $[1,4]$. Many studies have indicated that the same underlying risk factors may increase the probability of developing both psychotic disorder and PLEs $[1,3]$. These are for example, trauma [2, 5, 6], childhood abuse [7] or psychoactive substances usage [1]. Both psychosis and PLEs are more common in the younger population [8].

Sense of coherence (SOC) is the core element of Antonovsky's salutogenic model: a theory that explains the relations between stress, coping, and health by concentrating on the factors that help people stay healthy rather than those that lead to disease (pathogenic orientation) [9]. SOC is a global orientation that helps a person to successfully cope with the demands of life. It consists of three elements: comprehensibility - the feeling that the inner and outer stimuli are coherent and clear; manageability a belief that one has enough resources and is able to successfully meet the demands posed by these stimuli; and meaningfulness - the sense that life's challenges are worthy of engagement [9]. In other words, SOC level expresses the degree to which a person believes that the world is rational and predictable or is "making sense, cognitively, instrumentally and mentally" [10, p. 15].

It has been demonstrated that SOC relates to resilience and hardiness [11] and has a buffering effect on the psychological well-being [12]. Moreover, low-level SOC was showed to be linked to a wide range of psychiatric symptoms [13]. Individuals with depressive, anxiety, neurological, and psychotic disorders were demonstrated to have lower-level SOC than people without any psychiatric diagnosis [14]. SOC has been also found to be negatively correlated with psychotic symptoms in a sample of patients diagnosed with schizophrenia and schizoaffective disorder $[15,16]$. Moreover, among patients with schizophrenia, a heightened SOC has been associated with a higher self-reported quality of life and greater effectiveness of psychoeducational intervention [17].

The aim of the current study was to test the relationship between SOC and PLEs in general population of healthy subjects, and to address an existing research gap on that topic. It was predicted that lower-level SOC is related to higher level of both positive and negative PLEs. This assumption is based on Antonovsky's theory [9], as SOC is a general resource connected to better psychological functioning, being negatively related to general psychopathology, and also on the basis on previous findings showing a lower-level SOC in patients diagnosed with schizophrenia $[15,16]$. It was also proposed that the expected mechanism linking PLEs and SOC could be bidirectional. PLEs may cause feelings of confusion and alienation (positive PLEs are hard to understand and are often misunderstood by others; negative PLEs consist of emotional and social withdrawal) which may lead to weaker belief in the world which is predictable and worthy of engagement (low SOC). In turn, a person who perceives the world as unpredictable and incomprehensible may become more distrustful and vigilant, and in consequence develop more PLEs (e.g., beliefs resembling delusions). The pilot study on a smaller sample followed by the larger, main study were conducted to test these hypotheses.

\section{PILOT STUDY}

\section{Methods}

\section{Participants}

The pilot study was conducted online among Polishspeaking Internet users. The participants were recruited via social media. They volunteered and did not receive any award or payment. The sample consisted of 102 people: 69 females, 31 males, and two non-binary persons. Their age ranged from 18 to $84(\mathrm{M}=38.15 ; \mathrm{SD}=14.32)$ and a majority had a degree $(54.9 \%$ a master's degree, $13.7 \%$ a bachelor's degree) or were students (13.7\%). The participants who used psychoactive substances less than three months prior to the study or had been diagnosed with a mental disorder were excluded from further analysis, as these factors could have affected the research results (the effects of the substance usage or symptoms of another psychopathology might be mistaken as the actual PLEs). The final sample consisted of 82 people (57 females). The sample size was calculated with the $G^{\star}$ Power [18].

\section{Materials and procedure}

First, the participants were asked for basic demographic variables (age, education, gender), following which they were presented with a short set of questions about the exclusion variables: a mental disorder diagnosis and psychoactive substance usage.

PLEs were measured with the positive and negative symptoms subscales of the Polish version of the Community Assessment of Psychic Experiences (CAPE) [19, 20], which consists of 18 and 14 items respectively. In the original scale, individuals also mark a distress level connected with every symptom they experience, but in the 
present study it was decided that the distress measure should be removed to shorten the questionnaire and reduce the possible dropout rate. Cronbach's a for the Polish version of the CAPE was: for the total frequency scores (positive and negative) $\alpha=0.90$, for negative symptoms $\alpha=0.70$, and for positive symptoms $\alpha=0.81$ [20].

SOC was measured with the Polish adaptation of Antonovsky's Orientation to Life Questionnaire (SOC-29) [21]. The scale consists of 29 items divided into subscales corresponding to the three components of SOC: comprehensibility (11 questions), manageability (10 questions) and meaningfulness (8 questions). Individuals mark their answers using a 7-point Likert-like scale. The Cronbach's $\alpha$ was 0.92 for the whole scale, 0.78 for comprehensibility, 0.72 for manageability, and 0.68 for meaningfulness.

\section{Analysis plan}

The aim of the study was to find out if SOC is a nonredundant predictor of the incidence of PLEs and, if so, which of its components explain the variance in PLEs. Correlation and regression analyses were conducted. Four regression analyses were performed, separately for negative and positive PLEs, firstly with an overall SOC score and then with SOC subscales as predictors. Age and gender were used as control variables as the two factors were found to be related to PLEs: specifically, as PLEs are more common among men and young people [1, 8]. Also, despite SOC being generally a stable trait, it was found to increase in the course of life [22]. In the second step of hierarchical regression analysis, the other PLEs type was added as controlled variable.

\section{Results}

No missing data issue occurred due to procedure design (reminders to answer all the questions were included). Almost 70\% (69 out of 102) of the participants claimed to have never used any psychoactive substances and the majority (24) of those who did, used drugs for the last time more than six months prior to the study. Only two people self-reported using drugs regularly (at least once a week); 19 participants (18.6\%) had been diagnosed with a mental disorder before (schizophrenia and personality, affective, and anxiety disorders). As stated above, the participants who used psychoactive substances less than three months prior to the study or had been diagnosed with mental disorders were excluded from further analysis, and the final sample consisted of 82 people (57 females).

Descriptive statistics of tested variables are presented in Table 1.

\section{Correlation analysis}

The results of correlation analysis are presented in Table 2. As predicted, the correlations between SOC and the CAPE subscales were all significant and negative. Age was positively and significantly correlated with SOC in both the overall scores and subscales. It was also negatively correlated with PLEs, excluding the positive symptoms (for detailed results, see Table 2).

\section{Regression analysis}

Hierarchical multiple regression analysis was conducted to test if SOC is a non-redundant predictor of subclinical psychotic symptoms. Age and gender were the two other predictors tested in the model. The analysis was conducted separately for positive and negative PLEs. In the second step, the other PLEs type (negative for positive PLEs prediction and vice versa) was added as a controlled variable.

The first model tested if the SOC overall score, age, and gender are predictors of frequency of positive PLEs. The model was statistically significant $(F(3,77)=4.51$; $p=0.006)$ and, according to the adjusted coefficient of determination, it explained about $12 \%$ of the variance in the CAPE positive subscale scores. The Durbin-Watson statistic was acceptable (1.61) and other assumptions of regression analysis were met. SOC was found to be a negative predictor of the CAPE scores, explaining about $14 \%$ of its variance. Age and gender did not reach the level of statistical significance as predictors. In the second step, negative PLEs were added as a predictor. The model remained significant $(F(4,76)=3.35 ; p=0.014)$, explaining approximately $11 \%$ of the variance in positive PLEs.

Table 1. Sense of coherence (SOC) and psychotic-like experiences (Community Assessment of Psychic Experiences - CAPE) scores in pilot study

\begin{tabular}{|l|c|c|c|}
\hline & Min & Max & M \\
\hline SOC sum & 57 & 183 & 132.18 \\
\hline SOC comprehensibility & 23 & 68 & 43.95 \\
\hline SOC manageability & 22 & 66 & 48.07 \\
\hline SOC meaningfulness & 10 & 56 & 40.16 \\
\hline Negative symptoms & 15 & 54 & 26.09 \\
\hline Positive symptoms & 20 & 42 & 27.49 \\
\hline Positive and negative symptoms (sum) & 35 & 78 & 5.94 \\
\hline
\end{tabular}


Table 2. The correlations between the variables in pilot study

\begin{tabular}{|c|c|c|c|c|c|c|c|c|}
\hline & SOC sum & COM (SOC) & $\mathrm{MN}(\mathrm{SOC})$ & MF(SOC) & $\begin{array}{l}\text { Positive } \\
\text { (CAPE) }\end{array}$ & $\begin{array}{l}\text { Negative } \\
\text { (CAPE) }\end{array}$ & $\begin{array}{l}\text { Positive and } \\
\text { negative }\end{array}$ & Age \\
\hline SOC sum & 1 & & & & & & & \\
\hline COM (SOC) & $0.84^{* * *}$ & 1 & & & & & & \\
\hline MN (SOC) & $0.93^{* * *}$ & $0.67^{* * *}$ & 1 & & & & & \\
\hline MF (SOC) & $0.90^{* * *}$ & $0.59^{* * *}$ & $0.80^{* * *}$ & 1 & & & & \\
\hline Positive (CAPE) & $-0.35^{* * *}$ & $-0.38^{* * *}$ & $-0.33^{* *}$ & $-0.25^{*}$ & 1 & & & \\
\hline Negative (CAPE) & $-0.70^{* * *}$ & $-0.45^{* * *}$ & $-0.64^{* * *}$ & $-0.75^{* * *}$ & $0.25^{*}$ & 1 & & \\
\hline $\begin{array}{l}\text { Positive and } \\
\text { negative }\end{array}$ & $-0.70^{* * *}$ & $-0.53^{* * *}$ & $-0.64^{* * *}$ & $-0.68^{* * *}$ & $0.71^{* * *}$ & $0.86^{* * *}$ & 1 & \\
\hline Age & $0.32^{* *}$ & 0.21 & $0.31^{* *}$ & $0.34^{* *}$ & 0.02 & $-0.29^{* *}$ & -0.20 & 1 \\
\hline
\end{tabular}

${ }^{*} p<0.05 ;{ }^{* *} p<0.01 ;{ }^{* * *} p<0.001$

Com - comprehensibility, MN - manageability, MF - meaningfulness, Positive (CAPE) - positive and negative sum, CAPE, Negative (CAPE) - negative sum, CAPE

Negative PLEs were not a non-redundant predictor of dependent variable and the percentage of the variance explained by SOC dropped to $7 \%$.

Because the first model was statistically significant, the second analysis was conducted to test which of the components of the sense of coherence (comprehensibility, manageability, or meaningfulness) explained the variance in the positive subscale of the CAPE. Again, age, and gender were used as control variables, and negative PLEs were added in the second step.

The second model was also statistically significant $(F(5,75)=3.15 ; p=0.012)$ and it explained almost $12 \%$ of the variance in the positive PLEs frequency. The assumptions of regression analysis were met: the Durbin-Watson statistic was acceptable (1.56), the distribution of residuals was normal, and there was not collinearity of predictors. None of the predictors reached the statistical significance level, however comprehensibility was on the edge $(p=0.057)$ and explained about $4 \%$ of positive PLEs variance. When negative PLEs were added in the second step, the model remained significant $(F(6,74)=2.73 ; p=0.019)$, still explaining $12 \%$ of the variance in dependent variable. Again, comprehensibility was the only predictor almost reaching statistical significance $(p=0.055)$, explaining about $4 \%$ of positive PLEs variance. The results for the first four models are presented in Table 3.

Next, the regression analysis for negative PLEs frequency was conducted. The model with the SOC overall scores, age, and gender as predictors was statistically significant $(F(3,77)=25.94 ; p<0.001)$ and explained about $48 \%$ of the variance in the CAPE negative subscale scores. All assumptions of regression analysis were met, and the Durbin-Watson statistic was acceptable (1.88). SOC was found to be a negative predictor of the negative PLEs frequency and explained about $42 \%$ of its variance. When positive PLEs were added in the second step, the model remained significant $(F(4,76)=19.22 ; p<0.001)$ and explained about $48 \%$ of the variance of dependent variable.
Again, SOC was found to be the only significant predictor of negative PLEs.

The model including the SOC subscales was also significant $(F(5,75)=20.40 ; p<0.001)$ and, according to adjusted coefficient of determination, it explained about $55 \%$ of variance in negative PLEs frequency. The Durbin-Watson statistic was again acceptable (2.01) and all the assumptions of regression analysis were met. Meaningfulness was found to be the only non-redundant, negative predictor of negative PLEs frequency, and explained about $15 \%$ of its variance. Next, positive PLEs were added to the model. It remained significant $(F(6,74)=17.03 ; p<0.001)$ and explained approximately $55 \%$ of the dependent variable variance. Once more, only meaningfulness was found to be a non-redundant predictor of negative PLEs, explaining about $15 \%$ of their variance. Table 4 presents the results for the models 5-8.

\section{Discussion}

The aim of the pilot study was to test the association between SOC and PLEs in a group of healthy adults. The results were consistent with the prediction: the SOC was strongly, negatively correlated with the CAPE scores. Moreover, it was found that SOC predicted negative and positive PLEs frequency. The relation was still significant with age and gender controlled, so this result cannot be explained by SOC raising and the frequency of PLEs decreasing during the lifetime, or by the higher occurrence of PLEs in males. It is important to note that relations between SOC and PLEs were different for positive and negative subclinical psychotic symptoms. The correlations of all SOC components were much higher for the negative than for the positive subscale of CAPE. Also, correlation with comprehensibility was at its weakest for negative PLEs and the strongest for the positive. When the subscales of SOC-29 were tested in the regression analysis, comprehensibility was the only predictor of the positive PLEs approaching the statistical signifi- 
The sense of coherence in healthy individuals with psychotic-like experiences

Poczucie koherencji u zdrowych osób z doświadczeniami podobnymi do psychotycznych

Table 3. Multiple regression analysis with sense of coherence (SOC) on positive psychotic-like experiences (PLEs) in pilot study

\begin{tabular}{|c|c|c|c|c|c|c|}
\hline Predictors & $B$ & Beta & $r_{\text {semi }}$ & $\%$ of variance & $t$ & $p$ \\
\hline \multicolumn{7}{|l|}{ Model 1} \\
\hline (Constant) & 35.56 (Cl: 30.01 to 41.06$)$ & & & & 12.88 & $<0.001$ \\
\hline SOC sum & -0.07 (Cl: -0.11 to -0.03$)$ & -0.40 & -0.37 & $14 \%$ & -3.55 & 0.001 \\
\hline Age & 0.05 (Cl: -0.02 to 0.12$)$ & 0.15 & 0.15 & $2 \%$ & 1.39 & 0.170 \\
\hline Gender & $-0.65(\mathrm{Cl}:-2.81$ to 1.51$)$ & -0.06 & -0.06 & $<1 \%$ & -0.60 & 0.551 \\
\hline \multicolumn{7}{|l|}{ Model 2} \\
\hline (Constant) & 34.65 (Cl: 22.83 to 46.47$)$ & & & & 5.84 & $<0.001$ \\
\hline SOC sum & -0.07 (Cl: -0.12 to -0.01$)$ & -0.38 & -0.26 & $7 \%$ & -2.48 & 0.015 \\
\hline Age & 0.05 (Cl: -0.02 to 0.13$)$ & 0.16 & 0.15 & $2 \%$ & 1.39 & 0.170 \\
\hline Gender & -0.67 (Cl: -2.86 to 1.52$)$ & -0.07 & -0.07 & $<1 \%$ & -0.61 & 0.542 \\
\hline Negative PLEs & 0.02 (Cl: -0.20 to 0.24$)$ & 0.03 & 0.02 & $<1 \%$ & 0.17 & 0.862 \\
\hline \multicolumn{7}{|l|}{ Model 3} \\
\hline (Constant) & 36.63 (Cl: 30.91 to 42.35$)$ & & & & 12.76 & $<0.001$ \\
\hline Comprehensibility & -0.14 (Cl: -0.29 to 0.0$)$ & -0.28 & -0.20 & $4 \%$ & -1.94 & 0.057 \\
\hline Manageability & -0.11 (Cl: -28 to 0.07$)$ & -0.23 & -0.13 & $2 \%$ & -1.20 & 0.234 \\
\hline Meaningfulness & 0.03 (Cl: -0.13 to 0.18$)$ & 0.07 & 0.04 & $<1 \%$ & 0.36 & 0.721 \\
\hline Age & 0.04 (Cl: -0.03 to 0.12$)$ & 0.13 & 0.12 & $1 \%$ & 1.17 & 0.246 \\
\hline Gender & -0.29 (Cl: -2.50 to 1.92$)$ & -0.03 & -0.03 & $<1 \%$ & -0.26 & 0.793 \\
\hline \multicolumn{7}{|l|}{ Model 4} \\
\hline Constant & 32.31 (Cl: 20.20 to 44.43$)$ & & & & 5.31 & $<0.001$ \\
\hline Comprehensibility & -0.14 (Cl: -0.29 to 0.00$)$ & -0.29 & -0.21 & $4 \%$ & -1.95 & 0.055 \\
\hline Manageability & -0.10 (Cl: -0.29 to 0.08$)$ & -0.22 & -0.12 & $1 \%$ & -1.11 & 0.270 \\
\hline Meaningfulness & 0.07 (Cl: -0.12 to 0.25$)$ & 0.15 & 0.08 & $<1 \%$ & 0.72 & 0.475 \\
\hline Age & 0.05 (Cl: -0.03 to 0.12$)$ & 0.14 & 0.13 & $2 \%$ & 1.21 & 0.230 \\
\hline Gender & -0.34 (Cl: -2.55 to 1.88$)$ & -0.03 & -0.03 & $<1 \%$ & -0.30 & 0.764 \\
\hline Negative PLEs & 0.10 (Cl: -0.14 to 0.34$)$ & 0.13 & 0.09 & $<1 \%$ & 0.81 & 0.423 \\
\hline
\end{tabular}

cance level $(p=0.057)$. This suggested that experiencing more hallucinatory or delusional symptoms may be related to one's sense of understanding the world as one's inner and outer stimuli are incompatible. At the same time, having a strong sense of understanding the world might also influence positive PLEs by making these experiences easier to rationalize or less stressful.

On the other hand, for the negative PLEs the strongest correlation was found with meaningfulness (even stronger than for the overall SOC scores), and this component of SOC was also found to be the best predictor of negative PLEs frequency. It is likely that people who perceived their lives as lacking a purpose and who were less willing to engage in the life's challenges were also prone to social withdrawal, apathy or alogia, less active, and therefore tended to report negative psychotic symptoms. The cognitive component of SOC - comprehensibility - was not relevant in the case of negative PLEs. The findings suggest that SOC is differently related to positive and negative PLEs

Interestingly, not only did SOC remain a significant predictor of PLEs when the other PLEs type was controlled, but also negative PLEs did not predict positive PLEs frequency and vice versa. At the same time, in all models, the percentage of variance explained by SOC slightly decreased. Alongside with the moderate correlation between PLEs types, it suggested some but not total independence between these two groups of subthreshold symptoms.

\section{THE MAIN STUDY}

The results of the pilot study were promising but the sample itself was not large enough, so the second study was performed to test the hypotheses with the aim to draw more solid conclusions. Moreover, it was decided to add symptoms of depression to the model as they relate to both PLEs (positively) [23, 24] and SOC (negatively) [25]. It was assumed that depressive symptoms would be negatively correlated with SOC and positively with PLEs, and that they will be a positive predictor of the latter. Moreover, it was expected that SOC would remain a significant predictor of PLEs, even after including depressive symptoms in regression analysis. 
Table 4. Multiple regression analysis with sense of coherence (SOC) on negative psychotic-like experiences (PLEs) in pilot study

\begin{tabular}{|c|c|c|c|c|c|c|}
\hline Predictors & $B$ & Beta & $r_{\text {semi }}$ & $\%$ of variance & $t$ & $p$ \\
\hline \multicolumn{7}{|l|}{ Model 5} \\
\hline (Constant) & 47.23 (Cl: 41.55 to 52.91$)$ & & & & 16.57 & $<0.001$ \\
\hline SOC sum & $-0.16(\mathrm{Cl}:-0.20$ to -0.12$)$ & -0.69 & -0.65 & $42 \%$ & -8.03 & $<0.001$ \\
\hline Age & $-0.04(\mathrm{Cl}:-0.11$ to 0.04$)$ & -0.08 & -0.08 & $<1 \%$ & -0.93 & 0.354 \\
\hline Gender & 1.29 (Cl: -0.94 to 3.52$)$ & 0.09 & 0.09 & $<1 \%$ & 1.15 & 0.253 \\
\hline \multicolumn{7}{|l|}{ Model 6} \\
\hline (Constant) & 46.50 (Cl: 36.35 to 56.65$)$ & & & & 9.12 & $<0.001$ \\
\hline SOC sum & $-0.16(\mathrm{Cl}:-0.21$ to -0.12$)$ & -0.68 & -0.59 & $35 \%$ & -7.34 & $<0.001$ \\
\hline Age & -0.04 (Cl: -0.11 to 0.04$)$ & -0.08 & -0.08 & $<1 \%$ & -0.94 & 0.349 \\
\hline Gender & 1.30 (Cl: -0.95 to 3.55$)$ & 0.10 & 0.09 & $<1 \%$ & 1.15 & 0.252 \\
\hline Positive PLEs & 0.02 (Cl: -0.22 to 0.26$)$ & 0.02 & 0.01 & $<1 \%$ & 0.17 & 0.862 \\
\hline \multicolumn{7}{|l|}{ Model 7} \\
\hline (Constant) & 44.77 (Cl: 39.24 to 50.30$)$ & & & & 16.12 & $<0.001$ \\
\hline Comprehensibility & 0.01 (Cl: -0.13 to 0.16$)$ & 0.02 & 0.02 & $<1 \%$ & 0.19 & 0.847 \\
\hline Manageability & -0.08 (Cl: -0.26 to 0.10$)$ & -0.12 & -0.07 & $<1 \%$ & -0.87 & 0.388 \\
\hline Meaningfulness & -0.39 (Cl: -0.54 to -0.24$)$ & -0.66 & -0.39 & $15 \%$ & -5.11 & $<0.001$ \\
\hline Age & -0.02 (Cl: -0.09 to 0.05$)$ & -0.04 & -0.04 & $<1 \%$ & 1.48 & 0.628 \\
\hline Gender & 0.45 (Cl: -1.69 to 2.58$)$ & 0.03 & 0.03 & $<1 \%$ & 0.41 & 0.680 \\
\hline \multicolumn{7}{|l|}{ Model 8} \\
\hline Constant & 41.46 (Cl: 31.59 to 51.34$)$ & & & & 8.37 & $<0.001$ \\
\hline Comprehensibility & 0.03 (Cl: -0.12 to 0.17 ) & 0.04 & 0.03 & $<1 \%$ & 0.37 & 0.716 \\
\hline Manageability & -0.07 (Cl: -0.25 to 0.11$)$ & -0.10 & -0.06 & $<1 \%$ & -0.75 & 0.457 \\
\hline Meaningfulness & -0.39 (Cl: -0.54 to -0.24$)$ & -0.66 & -0.39 & $15 \%$ & 5.12 & $<0.001$ \\
\hline Age & -0.02 (Cl: -0.09 to 0.05$)$ & -0.05 & -0.04 & $<1 \%$ & -0.59 & 0.557 \\
\hline Gender & 0.47 (Cl: -1.67 to 2.62$)$ & 0.03 & 0.03 & $<1 \%$ & 0.44 & 0.663 \\
\hline Positive PLES & 0.09 (Cl: -0.13 to 0.31$)$ & 0.07 & 0.06 & $<1 \%$ & 0.81 & 0.423 \\
\hline
\end{tabular}

\section{Methods}

\section{Participants}

The main study was also conducted online among Polish-speaking Internet users. The participants were recruited through advertisements in social media and all of them were volunteers. The sample consisted of 300 people: 227 females, 66 males, 6 non-binary persons and one person identifying as genderqueer; in age between 15 to 65 years $(M=21.72 ; S D=5.67)$. The majority were educated to a degree level or were students (59.7\%, respectively $25.4 \%$ and $34.3 \%$ ) with strong representation of high school graduates (39\%). Again, all volunteers who had used psychoactive substances less than three months before the study or had been diagnosed with a mental disorder were excluded from further analysis. The final sample consisted of 215 people (162 females, 50 males, 3 non-binary persons).

\section{Materials and procedure}

The procedure was almost identical as that applied in the pilot study: first, participants were asked to provide basic demographic variables (age, education, gender) and give information about the variables that could exclude them from the study: a mental disorder diagnosis and psychoactive substance usage. PLEs were again measured by the positive and negative symptoms subscales from the Community Assessment of Psychic Experiences (CAPE) [19,20], and SOC by the Polish adaptation of Antonovsky's Orientation to Life Questionnaire (SOC-29) [21]. The only difference with the pilot study was the addition of depressive symptoms measurement, which was performed with the Polish version of the Patient Health Questionnaire-9 (PHQ-9) [26]. PHQ-9 is a short screening tool consisting of 9 questions that correspond with the DSM 5 symptoms of depression [27]. Participants mark their responses on 0-3 Likert-like scale. The Polish version of PHQ-9 has good psychometric qualities [27].

\section{Analysis plan}

The aim of the study was to replicate results of the pilot study. Again, correlation and regression analyses were conducted to test the relationship between SOC and PLEs. 
Four regression analyses were performed, separately for negative and positive PLEs; firstly with an overall SOC score, and then with SOC subscales as predictors. Age, gender were used as control variables In the second step of hierarchical regression analysis, the other PLEs type and depressive symptoms ware added as controlled variables.

\section{Results}

The procedure design (online questionnaire with reminders to fill in all the questions) prevented the issue of missing data. The majority of the participants $(68.3 \%$, i.e., 205 out of 300) had never used psychoactive substances, 37 (12.3\%) used them less than three months before the study and only 11 (3.7\%) used drugs regularly. 58 (19.3\%) participants had ever been diagnosed with a mental disorders (affective, eating, and anxiety disorders, PTSD or personality disorders, including schizotypal personality disorder). Similarly to the pilot study, all participants who used psychoactive substances less than three months prior to the study or had been diagnosed with a mental disorder were excluded from further analysis. As stated above, the final sample consisted of 215 people (162 females, 50 males, 3 non-binary persons). The descriptive statistics of the tested variables are presented in Table 5 .

\section{Correlation analysis}

The results of correlation analysis were consistent with the hypotheses. Correlations between SOC and CAPE were significant and negative for both overall scores and subscales, with the exception of the relation between meaningfulness and positive PLEs which failed to reach significance level. These correlations were generally stronger for negative than positive PLEs. Age was positively correlated with all SOC components, and negatively with PHQ-9 scores and negative, but not positive, PLEs. Finally, depressive symptoms were strongly negatively related to SOC but they related positively to PLEs. Detailed results are presented in Table 6.

\section{Regression analysis}

Hierarchical multiple regression analysis was conducted to test the relationship between SOC and PLEs - separately for positive and negative PLEs. Again, age and gender were also the predictors tested in the model. In the second step, the other PLEs type (negative for positive PLEs prediction and vice versa) and depressive symptoms (PHQ-9 score) were added as controlled variables. The Durbin-Watson statistic was acceptable (2.08).

Table 5. Sense of coherence (SOC), psychotic-like experiences (Community Assessment of Psychic Experiences - CAPE) and depressive symptoms (Polish version of the Patient Health Questionnaire-9 - PHQ-9) scores in main study

\begin{tabular}{|l|c|c|c|c|}
\hline & Min & Max & M & SD \\
\hline SOC sum & 67 & 180 & 118.13 & 24.64 \\
\hline SOC comprehensibility & 22 & 64 & 40.37 & 8.38 \\
\hline SOC manageability & 17 & 67 & 42.32 & 10.42 \\
\hline SOC meaningfulness & 11 & 53 & 35.44 & 9.56 \\
\hline Negative symptoms & 16 & 52 & 29.59 & 6.99 \\
\hline Positive symptoms & 20 & 64 & 30.87 & 5.85 \\
\hline Positive and negative symptoms (sum) & 39 & 106 & 60.46 & 10.72. \\
\hline Depressive symptoms & 0 & 25 & 9.04 & 5.67 \\
\hline
\end{tabular}

Table 6. The correlations between the variables in main study

\begin{tabular}{|c|c|c|c|c|c|c|c|c|c|}
\hline & SOC sum & $\begin{array}{l}\text { COM } \\
\text { (SOC) }\end{array}$ & $\begin{array}{l}\text { MN } \\
\text { (SOC) }\end{array}$ & $\begin{array}{c}\text { MF } \\
\text { (SOC) }\end{array}$ & $\begin{array}{l}\text { Positive } \\
\text { (CAPE) }\end{array}$ & $\begin{array}{c}\text { Negative } \\
\text { (CAPE) }\end{array}$ & $\begin{array}{l}\text { Positive and } \\
\text { negative }\end{array}$ & $\begin{array}{l}\text { Depressive } \\
\text { symptoms }\end{array}$ & Age \\
\hline SOC sum & 1 & & & & & & & & \\
\hline COM (SOC) & $0.83^{* * *}$ & 1 & & & & & & & \\
\hline MN (SOC) & $0.92^{* * *}$ & $0.69^{* * *}$ & 1 & & & & & & \\
\hline MF (SOC) & $0.85^{* * *}$ & $0.51^{* * *}$ & $0.68^{* * *}$ & 1 & & & & & \\
\hline Positive (CAPE) & $-0.22^{* *}$ & $-0.25^{* * *}$ & $-0.24^{* *}$ & -0.07 & 1 & & & & \\
\hline Negative (CAPE) & $-0.66^{* * *}$ & $-0.51^{* * *}$ & $-0.56^{* * *}$ & $-0.65^{* * *}$ & $0.39^{* * *}$ & 1 & & & \\
\hline Positive and negative & $-0.55^{* * *}$ & $-0.47^{* * *}$ & $-0.50^{* * *}$ & $-0.46^{* * *}$ & $0.80^{* * *}$ & $0.87^{* * *}$ & 1 & & \\
\hline Depressive symptoms & $-0.68^{* * *}$ & $-0.50^{* * *}$ & $-0.63^{* * *}$ & $-0.62^{* * *}$ & $0.38^{* * *}$ & $0.72^{* * *}$ & $0.68^{* * *}$ & 1 & \\
\hline Age & $0.19^{* *}$ & $0.18^{* *}$ & $0.14^{*}$ & $0.17^{*}$ & 0.09 & $-0.27^{* * *}$ & $-0.23^{* * *}$ & $-0.16^{*}$ & 1 \\
\hline
\end{tabular}

${ }^{*} p<0.05,{ }^{* *} p<0.01,{ }^{* * *} p<0.001$

Com - comprehensibility, MN - manageability, MF- meaningfulness, Positive (CAPE) - positive and negative sum, CAPE, Negative (CAPE) - negative sum, CAPE 
Table 7. Multiple regression analysis with sense of coherence (SOC) on positive psychotic-like experiences (PLEs) in main study

\begin{tabular}{|c|c|c|c|c|c|c|}
\hline Predictors & B & Beta & $r_{\text {semi }}$ & $\%$ of variance & $t$ & $p$ \\
\hline \multicolumn{7}{|l|}{ Model 1} \\
\hline (Constant) & 40.03 (Cl: 35.20 to 44.85$)$ & & & & 16.36 & $<0.001$ \\
\hline SOC sum & -0.05 (Cl: -0.08 to -0.02$)$ & -0.21 & -0.20 & $4 \%$ & -3.05 & 0.003 \\
\hline Age & $-0.06(\mathrm{Cl}:-0.19$ to 0.08$)$ & -0.06 & -0.06 & $<1 \%$ & -0.85 & 0.399 \\
\hline Gender & -1.71 (Cl: -3.33 to -0.08$)$ & -0.14 & -0.14 & $2 \%$ & -2.10 & 0.040 \\
\hline \multicolumn{7}{|l|}{ Model 2} \\
\hline (Constant) & 17.77 (Cl: 8.77 to 26.78$)$ & & & & 3.89 & $<0.001$ \\
\hline SOC sum & 0.04 (Cl: -0.002 to 0.08$)$ & 0.17 & 0.12 & $1.5 \%$ & 1.87 & 0.063 \\
\hline Age & -0.002 (Cl: -0.13 to 0.12$)$ & -0.002 & 0.002 & $<1 \%$ & -0.03 & 0.975 \\
\hline Gender & $-1.34(\mathrm{Cl}:-2.86$ to 0.19$)$ & -0.11 & -0.11 & $1 \%$ & -1.72 & 0.086 \\
\hline Negative PLEs & 0.26 (Cl: 0.10 to 0.42$)$ & 0.31 & 0.20 & $4 \%$ & 3.18 & 0.002 \\
\hline Depressive symptoms & 0.27 (Cl: 0.08 to 0.47 ) & 0.27 & 0.17 & $3 \%$ & 2.72 & 0.007 \\
\hline \multicolumn{7}{|l|}{ Model 3} \\
\hline (Constant) & 40.60 (Cl: 35.73 to 45.48$)$ & & & & 16.41 & $<0.001$ \\
\hline Comprehensibility & $-0.12(\mathrm{Cl}:-0.25$ to 0.004$)$ & -0.17 & -0.13 & $2 \%$ & -1.91 & 0.057 \\
\hline Manageability & -0.13 (Cl: -25.00 to -0.01$)$ & -0.23 & -0.14 & $2 \%$ & -2.16 & 0.032 \\
\hline Meaningfulness & 0.11 (Cl: -0.001 to 0.22$)$ & 0.18 & 0.13 & $2 \%$ & 1.96 & 0.052 \\
\hline Age & -0.06 (Cl: -0.19 to 0.07$)$ & -0.06 & -0.06 & $<1 \%$ & -0.94 & 0.348 \\
\hline Gender & -1.49 (Cl: -3.10 to 0.13$)$ & -0.12 & -0.12 & $1 \%$ & -1.82 & 0.070 \\
\hline \multicolumn{7}{|l|}{ Model 4} \\
\hline Constant & 14.55 (Cl: 5.78 to 23.33$)$ & & & & 3.27 & 0.001 \\
\hline Comprehensibility & -0.06 (Cl: -0.17 to 0.06$)$ & -0.08 & -0.06 & $<1 \%$ & -0.95 & 0.343 \\
\hline Manageability & -0.06 (Cl: -0.17 to 0.05$)$ & -0.10 & -0.06 & $<1 \%$ & -1.04 & 0.300 \\
\hline Meaningfulness & 0.28 (Cl: 0.17 to 0.39 ) & 0.46 & 0.30 & $9 \%$ & 5.00 & $<0.001$ \\
\hline Age & 0.00 (Cl: -0.12 to 0.12$)$ & 0.00 & 0.00 & $<1 \%$ & 0.06 & 0.953 \\
\hline Gender & -0.99 (Cl: -2.46 to 0.47$)$ & -0.08 & -0.08 & $<1 \%$ & -1.34 & 0.183 \\
\hline Negative PLEs & 0.33 (Cl: 0.17 to 0.49$)$ & 0.40 & 0.25 & $6 \%$ & 4.17 & $<0.001$ \\
\hline Depressive symptoms & 0.28 (Cl: 0.09 to 0.47 ) & 0.27 & 0.17 & $3 \%$ & 2.86 & 0.005 \\
\hline
\end{tabular}

The first model tested if the SOC overall score, age, and gender are predictors of frequency of positive PLEs. The model was statistically significant $(F(3,211)=5.16$; $p=0.002$ ) but, according to the adjusted coefficient of determination, it explained only about $6 \%$ of the variance in the CAPE positive subscale scores. SOC was found to be a negative predictor of the CAPE scores, explaining about $4 \%$ of its variation. Gender predicted less than $2 \%$ of variation in positive PLEs frequency and it did not reach the statistical significance as a predictor.

In the second step, negative PLEs and depressive symptoms were added as predictors. The model remained significant $(F(5,209)=10.47 ; p<0.001)$, explaining approximately $18 \%$ of the variance in positive PLEs. The percentage of variance explained by SOC dropped to $1.5 \%$ and it became a redundant and positive predictor, almost reaching the significance level $(p=0.063)$. Both depressive symptoms and negative PLEs were non-redundant predictors of dependent variable, while age and gender failed to reach significance.
The second analysis was conducted with the SOC components as predictors. Again, age and gender were used as control variables, and negative PLEs and depressive symptoms were added in the second step. The Durbin-Watson statistic was acceptable (2.14). This model was also statistically significant $(F(5,209)=5.08$; $p<0.001)$ and it explained almost $9 \%$ of the variance in the positive PLEs frequency. Only manageability was found to be significant, negative predictor of dependent variable, explaining about $2 \%$ in its variance. Comprehensibility and meaningfulness almost reached the significance level (respectively $p=0.057$ and $p=0.052$ ) but, contrary to the expectations, meaningfulness was related to positive PLEs positively. Age and gender were not non-redundant predictors. When negative PLEs and depressive symptoms were added in the second step, the model remained significant $(F(7,207)=11.44$; $p<0.001$ ), explaining almost $26 \%$ of the variance in dependent variable. This time, meaningfulness was the only SOC component that successfully predicted variance in 
The sense of coherence in healthy individuals with psychotic-like experiences

Poczucie koherencji u zdrowych osób z doświadczeniami podobnymi do psychotycznych

Table 8. Multiple regression analysis with sense of coherence (SOC) on negative psychotic-like experiences (PLEs) in main study

\begin{tabular}{|c|c|c|c|c|c|c|}
\hline Predictors & $B$ & Beta & $r_{\text {semi }}$ & $\%$ of variance & $t$ & $p$ \\
\hline \multicolumn{7}{|l|}{ Model 5} \\
\hline (Constant) & 55.16 (Cl: 50.78 to 59.54$)$ & & & & 24.82 & $<0.001$ \\
\hline SOC sum & $-0.18(\mathrm{Cl}:-0.21$ to -0.15$)$ & -0.64 & -0.62 & $38 \%$ & -12.36 & $<0.001$ \\
\hline Age & -0.18 (Cl: -0.30 to 0.06$)$ & -0.15 & -0.15 & $2 \%$ & -2.92 & 0.004 \\
\hline Gender & $-0.34(\mathrm{Cl}:-1.82$ to 1.14$)$ & -0.02 & -0.02 & $<1 \%$ & -0.46 & 0.648 \\
\hline \multicolumn{7}{|l|}{ Model 6} \\
\hline (Constant) & 32.36 (Cl: 25.97 to 38.76$)$ & & & & 9.98 & $<0.001$ \\
\hline SOC sum & -0.09 (Cl: -0.12 to -0.06$)$ & -0.31 & -0.23 & $5 \%$ & -5.30 & $<0.001$ \\
\hline Age & $-0.15(\mathrm{Cl}:-0.25$ to 0.05$)$ & -0.13 & -0.13 & $2 \%$ & -2.89 & 0.004 \\
\hline Gender & 0.52 (Cl: -0.76 to 1.79$)$ & 0.04 & -0.03 & $<1 \%$ & 0.80 & 0.427 \\
\hline Positive PLEs & 0.18 (Cl: 0.07 to 0.29 ) & 0.15 & 0.14 & $2 \%$ & 3.18 & 0.002 \\
\hline Depressive symptoms & 0.53 (Cl: 0.38 to 0.69 ) & 0.43 & 0.30 & $9 \%$ & 6.95 & $<0.001$ \\
\hline \multicolumn{7}{|l|}{ Model 7} \\
\hline (Constant) & 54.91 (Cl: 50.51 to 59.32$)$ & & & & 24.57 & $<0.001$ \\
\hline Comprehensibility & -0.14 (Cl: -0.26 to 0.03$)$ & -0.17 & -0.12 & $1 \%$ & -2.59 & 0.013 \\
\hline Manageability & -0.07 (Cl: -0.18 to 0.04$)$ & -0.10 & -0.06 & $<1 \%$ & -1.28 & 0.201 \\
\hline Meaningfulness & -0.34 ( $\mathrm{Cl}:-0.44$ to -0.24$)$ & -0.47 & -0.34 & $12 \%$ & -6.87 & $<0.001$ \\
\hline Age & -0.17 (Cl: -0.29 to 0.05$)$ & -0.14 & -0.14 & $2 \%$ & -2.84 & 0.005 \\
\hline Gender & -0.60 (Cl: -2.06 to 0.85$)$ & 0.04 & 0.04 & $<1 \%$ & -0.82 & 0.416 \\
\hline \multicolumn{7}{|l|}{ Model 8} \\
\hline Constant & 31.55 (Cl: 25.34 to 37.77$)$ & & & & 10.01 & $<0.001$ \\
\hline Comprehensibility & -0.08 (Cl: -0.18 to 0.02$)$ & -0.10 & -0.07 & $<1 \%$ & -1.67 & 0.096 \\
\hline Manageability & 0.05 (Cl: -0.05 to 0.14$)$ & 0.07 & 0.04 & $<1 \%$ & 0.96 & 0.336 \\
\hline Meaningfulness & -0.27 (Cl: -0.36 to -0.18$)$ & -0.37 & -0.24 & $6 \%$ & -5.87 & $<0.001$ \\
\hline Age & -0.14 (Cl: -0.24 to -0.04$)$ & -0.12 & -0.11 & $1 \%$ & -2.74 & 0.007 \\
\hline Gender & 0.26 (Cl: -0.98 to 1.50$)$ & 0.02 & 0.02 & $<1 \%$ & 0.42 & 0.678 \\
\hline Positive PLEs & 0.23 (Cl: 0.12 to 0.35$)$ & 0.20 & 0.17 & $3 \%$ & 4.17 & $<0.001$ \\
\hline Depressive symptoms & 0.49 (Cl: 0.34 to 0.64$)$ & 0.39 & 0.27 & $7 \%$ & 6.42 & $<0.001$ \\
\hline
\end{tabular}

positive PLEs frequency. Negative PLEs and depressive symptoms were two other non-redundant predictors of the dependent variable. Detailed results for the first four models are presented in Table 7.

Next, the regression analysis for negative PLEs frequency was conducted. First analysis included SOC overall scores, age, and gender as predictors with depressive symptoms and positive PLEs added in the second step. The Durbin-Watson statistic for this analysis was again acceptable (2.08).

The model from the first step was statistically significant $(F(3,211)=60.32 ; p<0.001)$ and explained about $45 \%$ of the variance in the CAPE negative subscale scores. SOC and age were found to be negative predictors of the negative PLEs frequency, explaining about $38 \%$ and $2 \%$ of its variance respectively. When positive PLEs and depressive symptoms were added in the second step, the model remained significant $(F(5,209)=65.77$; $p<0.001$ ) and explained about $60 \%$ of the variance of de- pendent variable. SOC and age remained significant, negative predictors of negative PLEs frequency, however the power of their prediction dropped. Both added predictors were significant.

Next, models including the SOC subscales were tested. The Durbin-Watson statistic was again acceptable (2.03). The model from the first step of the analysis was significant $(F(5,209)=40.21 ; p<0.001)$ and, according to adjusted coefficient of determination, it explained about $48 \%$ of variance in negative PLEs frequency. Comprehensibility and meaningfulness were found to be the nonredundant, negative predictors of negative PLEs frequency, explaining respectively $1.5 \%$ and $12 \%$ of its variance. Again, age was also a negative predictor of the dependent variable and explained about $2 \%$ of the variance in negative CAPE subscale scores. When positive PLEs and depressive symptoms were added to the model, it remained significant $(F(7,207=53.18 ; p<0.001)$ and explained approximately $63 \%$ of the dependent variable variance. 
Meaningfulness and age remained non-redundant negative predictors of negative PLEs, explaining respectively approximately $6 \%$ and $1 \%$ of their variance. Both positive PLEs and depressive symptoms were significant predictors of the dependent variable variance, explaining positively $3 \%$ and $7 \%$ of it. Table 8 presents detailed results for each model.

\section{Discussion}

The aim of the main study was to replicate the pilot study results and expand the analysis. Correlation analysis results were consistent with the hypotheses: SOC and PLEs, both in their overall scores and subscales, were negatively related (with the exception of the relation between meaningfulness and positive PLEs). As in the pilot study, correlations were stronger for the negative than positive PLEs. The relation between PHQ-9 scores and other variables were also as expected: strong, negative with SOC and positive with PLEs. The opposite was true for age: it was negatively correlated with PLEs and positively with SOC, which is consistent with the literature of the subject $[1,8,22]$.

Results of the regression analysis for the negative PLEs confirmed the hypotheses and replicated those yielded by the pilot study. SOC successfully and negatively predicted frequency of these kind of PLEs, both when age and gender were controlled, and when positive PLEs and depressive symptoms were added to the model. Moreover, when SOC components were tested, meaningfulness and comprehensibility were found to be negative predictors of the negative PLEs. However, comprehensibility, the cognitive component of SOC, explained only a minor percent of their variance and failed to reach significance level when depressive symptoms and positive PLEs were controlled. On the other hand, meaningfulness remained a non-redundant predictor of the dependent variable. It was also the component of SOC that correlated with negative PLEs the strongest. This results confirms that meaningfulness is an important factor related with the negative PLEs. It is only logical that people who are willing to engage in the life's challenges and are able to see a clear purpose in their lives [10], are less likely to experience feelings of emptiness, withdrawal or apathy.

The findings presented above put forward one more argument in support of the psychosis-continuum hypothesis by showing similar relations between subclinical psychosis symptoms and SOC, as these can be observed also between fully-developed psychosis and SOC $[15,16]$. These results also support Antonovsky's idea of SOC as a general health resource [9].

However, regression analysis results for the positive PLEs were a little surprising. SOC was a non-redundant negative predictor of the positive PLEs while age and gender of the participants were controlled, but when depressive symptoms and negative PLEs were included in the model, SOC predicted positive PLEs frequency only at the trend level $(p=0.063)$. When the components of SOC were tested as predictors, each of them explained about $2 \%$ of the variance in positive PLEs frequency, but only manageability was significant, while meaningfulness and comprehensibility only approached but failed to reach the significance level. When negative PLEs and depressive symptoms were added to the model, meaningfulness became the only non-redundant predictor among the SOC components. However, contrary to the hypothesis, it predicted the positive PLEs frequency positively. These results were not expected but can be explained. SOC (both overall score and components of manageability and comprehensibility) did successfully predict scores of the positive subscale of CAPE only when the other psychopathological symptoms were not controlled. It seems that SOC is related to positive PLEs not directly but via its negative relation to psychopathology, especially negative PLEs - whose frequency SOC did predict significantly. Moreover, in contrast to the pilot study results, in the main study negative and positive PLEs were significant predictors of each other. This inconsistency is not surprising as various PLEs occur together [4] and the relation was not discovered in the pilot study due to its limited power. Negative PLEs impact on positive PLEs as an explanation of this result can find some support in the phenomenology of fully-developed psychosis: many psychiatrists agree that it is the negative, not the positive symptoms that are necessarily present to diagnose schizophrenia [28-30].

Positive predictive power of the meaningfulness on the positive PLEs frequency is more surprising, with two important observations. Firstly, these two factors were not correlated in the study. Secondly, meaningfulness was a significant predictor of positive PLEs when other psychopathological factors were controlled. It is possible that the relation between meaningfulness and positive PLEs is multidirectional: there is some negative relation which is non-direct (similarly as in the case of the other components of SOC) but also an unexpected positive one. One possible explanation is that developing sense of purpose (and maybe even a mission) may be a specific coping strategy used by people with more frequent hallucination-like experiences and delusion-like ideas. On the other hand, some kind of positive PLEs (especially ideas resembling grandiose delusions or some persecutory delusions) may cause increased sense of mission and purpose, and higher willingness to engage in accomplishing this mission.

\section{LIMITATIONS}

Several limitations to the present study must be mentioned. The sample was not very large and consisted predominantly of women. The usage of self-report questionnaire may affect the validity of the data. Moreover, the sampling methods (Internet users) may have 
some impact on the results. There is also a probability that only people with lower-level PLEs participated in the study. Those who experience them more frequently might be avoiding taking part in psychological studies since they are more distrustful or more concerned about their symptoms. The cross-sectional design of the study precludes causal inferences; future studies should implement longitudinal design to address a causal relationship. Finally, only three control variables we tested and no possible moderators of relationship between SOC and PLEs were examined.

\section{CONCLUSIONS}

Although this study did not yield evidence about the cause-and-effect relationship between SOC and PLEs, it provided data concerning the significance of the re- lationship between them. Importantly, it demonstrated that positive and negative psychotic symptoms are related differently to SOC components. However, the main study failed to replicate all pilot study results. Both studies suggest that meaningfulness, a motivational component of SOC, is negatively related with negative PLEs, but the results for positive PLEs were more ambiguous. Further studies should test possible mediation effect between SOC and positive PLEs and test if SOC can have some buffering effect on developing PLEs, as it was shown to have such an effect on general psychological well-being [12]. If the buffering effect of SOC on PLEs could be found, it would have some important practical implications, suggesting that it would be beneficial to develop some interventions consolidating the SOC to prevent psychopathology or increase the quality of life in people with more frequent and intense PLEs.

\section{Acknowledgements/Podziękowania}

I would like to express my utmost gratitude to professor Katarzyna Prochwicz, $\mathrm{PhD}$, for her valuable advice and suggestions on the first version of this manuscript. I would also like to thank Jakub Antosz-Rekucki, MA, for proofreading.

\section{Conflict of interest/Konflikt interesu}

Absent./Nie występuje.

Financial support/Finansowanie

Absent./Nie występuje.

\section{References/Piśmiennicłwo}

1. van Os J, Linscott RJ, Myin-Germeys I, Delespaul P, Krabbendam L. A Systematic review and meta-analysis of the psychosis contiunuum: evidence for a psychosis proneness-persistence-impairment model of psychotic disorder. Psychol Med 2009; 39: 179-195.

2. Freeman D, Fowler D. Routes to psychotic symptoms: trauma, anxiety and psychosis-like experiences. Psychiatry Res 2009; 169: 107-112.

3. Kelleher I, Cannon M. Psychotic-like experiences in the general population: characterizing a high-risk group for psychosis. Psychol Med 2011; 41: 1-6.

4. Bourgin J, Tebeka S, Mallet J, Mazer N, Dubertret C, Le Strat Y. Prevalence and correlates of psychotic-like experiences in the general population. Schizophr Res 2020; 215: 371-377.

5. Lovatt A, Mason O, Brett C, Peters E. Psychotic-like experiences, appraisals and trauma. J Nerv Ment Dis 2010; 198: 813-819.

6. Popovic D, Schmitt A, Kaurani L, Senner F, Papiol S, Malchow B, et al. Childhood trauma in schizophrenia: current findings and research perspectives. Front Neurosci 2019; 13: 274.

7. Alemany S, Arias B, Aguilera M, Villa H, Moya J, Ibáňez MI, et al. Childhood abuse, the BDNF-Val66Met polymorphism and adult psychotic-like experiences. Br J Psychiatry 2011; 199: 38-42.

8. Verdoux H, van Os J. Psychotic symptoms in non-clinical populations and the continuum of psychosis. Schizophr Res 2002; 54: 59-65.

9. Antonovsky A. The structure and properties of the sense of coherence scale. Soc Sci Med 1993; 36: 725-733.

10. AntonovskyA. The salutogenic model as a theory to guide health promotion. Health Promot Int 1996; 11: 11-18.

11. Rizeanu S, Vasiliu D. Correlation between hardiness and the sense of coherence. Romanian J Exp Appl Psychol 2016; 7: 9-15. 
12. Gana K. Is sense of coherence a mediator between adversity and psychological well-being in adults? Stress Health 2001; 17: 77-83.

13. Ristkari T, Sourander A, Ronning J, Helenius H. Self-reported psychopathology, adaptative functioning and sense of coherence, and psychiatric diagnosis among young men. A population-based study. Soc Psychiatry Psychiatr Epidemiol 2006; 41: 523-531.

14. Mattisson C, Horstmann V, Bogren M. Relationship of SOC with sociodemographic variables, mental disorders and mortality. Scand J Public Health 2014; 42: 434-445.

15. Bengtsson-Tops A, Brunt D, Rask M. The structure of Antonovsky's sense of coherence in patients with schizophrenia and its relationship to psychopathology. Scand J Caring Sci 2005; 19: 280-287.

16. Bengtsson-Tops A, Hansson L. The validity of Antonovsky's Sense of Coherence measure in a sample of schizophrenic patients living in the community. J Adv Nurs 2001; 33: 432-438.

17. Gassmann W, Christ O, Lampert J, Berger H. The influence of Antonovsky's sense of coherence (SOC) and psychoeducational family intervention (PEFI) on schizophrenic outpatients' perceived quality of life: a longitudinal field study. BMC Psychiatry 2013; 13: 10.

18. Faul F, Erdfelder E, Buchner A, Lang AG. Statistical power analyses using $\mathrm{G}^{*}$ Power 3.1: tests for correlation and regression analyses. Behav Res Methods 2009; 41: 1149-1160.

19. Stefanis NC, Hanssen M, Smirnis NK, Avramopoulos DA, Evdokimidis IK, Stefanis CN, et al. Evidence that three dimensions of psychosis have a distribution in general population. Psychol Med 2002; 32: 347-358.

20. Gawęda $€$, Prochwicz K, Cella M. Cognitive biases mediate the relationship between temperament and character and psychotic-like experiences in healthy adults. Psychiatry Res 2015; 225: 50-57.

21. Koniarek J, Dudek B, Makowska Z. Kwestionariusz Orientacji Życiowej. Adaptacja The Sense of Coherence Questionnaire (SOC) A. Antonovsky’ego. Przegląd Psychologiczny 1993; 36: 491-502.

22. Nilsson KW, Leppert J, Simonsson B, Starrin B. Sense of coherence and psychological well-being: improvement with age. J Epidemiol Community Health 2010; 64: 347-352.

23. Isaksson J, Vadlin S, Olofsdotter S, Åslund C, Nilsson KW. Psychotic-like experiences during early adolescence predict symptoms of depression, anxiety, and conduct problems three years later: a community-based study. Schizophr Res 2020; 215: 190-195.

24. Saha S, Scott J, Varghese D, McGrath J. Anxiety and depressive disorders are associated with delusional-like experiences: a replication study based on a National Survey of Mental Health and Wellbeing. BJM Open 2012; 2: e001001. DOI: 10.1136/bmjopen-2012-001001.

25. Schnyder U, Büchi S, Sensky T, Klaghofer R. Antonovsky's sense of coherence: trait or state? Psychother Psychosom 2000; 69: 296-302.

26. Spitzer RL. Patient Health Questionnaire-9: PHQ-9. New York: New York State Psychiatric Institute; 2009.

27. Kokoszka A, Jastrzębski A, Orębski M. Ocena psychometrycznych właściwości polskiej wersji Kwestionariusza Zdrowia Pacjenta-9 dla osób dorosłych. Psychiatria 2016; 13: 187-193.

28. Jarema M. Schizofrenia. In: Jarema M (ed.). Psychiatria. Podręcznik dla studentów medycyny. Warszawa: Wydawnictwo Lekarskie PZWL; 2016, p. 73-124.

29. Marder SR, Galderisi S. The current conceptualization of negative symptoms in schizophrenia. World Psychiatry 2017; 16: 14-24.

30. Rabinowitz J, Levine SZ, Garibaldi G, Bugarski-Kirola D, Berardo CG, Kapur S. Negative symptoms have greater impact on functioning than positive symptoms in schizophrenia: Analysis of CATIE data. Schizophr Res 2012; 137: 147-150. 